\title{
骨想（骨相）を増大してはならない
}

一上座部仏教における不浄観の理論と実践——

\section{林隆 嗣}

1. はじめに 瞑想対象のイメージは, 精神集中が深化する過程で変容してい く，上座部仏教の理論によると，ある種の瞑想では，五感で直接的に知覚する様 相 (準備相, parikamma-nimitta) をそのまま心に留め置いていると, 目を閉じていて も思考で捉えられる観念的な心像（把捉相・取相, uggaha-n.) となり，そこからさ らに元の対象に類似したイメージでありながら, 色かたちも生滅もない対照相 (似相, patibhāga-n.) という様相に順次変化していくという.

ブッダゴーサの『清浄道論』（Visuddhimagga, Vism）における禅定の解説は，まず 業処の分類上最初に挙げられる地遍処（pathavī-kasināyatana）が基本となる. 土で 作った円盤を観察しながら，それを心に固着させて把捉相を保って集中を続け， さらに対象を土の色や個別の特徴のない対照相に変えていくすすでにパーリ経典 （DN III.268, 290, AN V.47）の中で「地遍を上に, 下に, 横に, 二つとなく, 無量に (appamāṇam) 想念する」という定型表現で示されるように，遍処の修行者は，こ の対照相を自覚的意識的に増大, 拡大させて初禅に入るとされる.Vismによる と, 対照相の増大は欲界定の段階から開始され ${ }^{11}$, 相の範囲を区切りながら自分 の部屋から外の空間へ，そして世界全体へと広げ（Vism 152, Dhs-a 195; cf. Vim 414b), 色界の初禅に入ってからも継続される。上座部では, こうした相の増大は遍処の 修行の場合に限定され, 身至念や不浄観や四梵住, 無色界禅などでは行われな い. 本稿では, 骨想 (atthhikasaññā) を究極とする不浄観瞑想において相を増大して はならない, という主張とその解釈をとりあげながら, 上座部における議論の展 開と多様化に注目しつつ, 実践と理論, 聖典と註釈の関係について考えたい.

\section{2. 相を増大させない——清浄道論』の場合 特に肉体を観察する瞑想修行} において相を増大させない理由として, Vism 111-112は, 範囲の限定と功徳のな さという2つの点を挙げる. 
「増大・不増大の観点から」といえば, これら四十業処のうちで十遍だけが増大されるべき である。...けれども身至念と不浄どもは増大させるべきではない. なぜかというと，〔身 体という】空間範囲（okāsa）に限定されていることによる.そして功徳がないことによ る. しかも，それらが空間範囲によって限定されているものであるという，そのことは修 養の方法（bhāvanānaya）において明らかになるだろう。一方, それら（不浄ども）が増大 されるとしても，污穢の集積 (kunaparāsi）だけが増大するのであって何の功徳もない. ${ }^{2)}$

Vism 180-181に示される上座部の古註釈群（複数形 Aț̣hakathā）の規程（vidhi）に 従えば，十不浄で相を把握する場合の 11 種の観点のうちの 1 つが「限定」（限界, pariccheda）である。例えば，膨脹相の場合，「この身体は，下は足の裏に，上は 髪の先に，横は皮膚によって限定されていて，しかも限定されている場に32の 污穢（kunapa）が充満しているだけであると, 確立させられるべし」と）とあり, 骨 相の場合も，「それぞれの骨の範囲による限定に基づいて確立させてから，この とき明瞭となって現れるものだけを把握して安止に達するべし」と）というように， 現実の身体部位の範囲そのままに観察すると規定されるため, 不浄観は対象の限 界を越えて増大させてはならない，というのがVismの見解である.

相を増大する功徳について言えば，大地などの相の増大に伴って知覚可能な空 間領域が広がることで天眼など5）の特殊能力を身につける（Vism 175-186）とされ るように，神通は八遍処を通じて得られるものである（Vism 373）が, 死体や骨の 相を拡大してもこうした功徳が生じない, というのが第2の理由である.

さらにここで経に類する未知の文書である Sopākapañhavyākarana から，「世尊 よ, 色であるという想念（色想）は遍在し, 骨であるという想念（骨想）は遍在し ていない」（vibhūtā bhagavā rūpasaññā, avibhūtā aț̣hikasañña) という一文を権威的に引用 して，「骨想 (骨相) が増大しない」ことの根拠にする ${ }^{6}$.

ところが, パーリ聖典の『長老偈』（Theragāthā, Th）第 18 偈（Singālapitā 長老）に は，「全体的に骨想をもってこの地面を満たした」（kevalaṃ aț̣hisaññāya aphari pathavim imam）と，骨想の拡大を示唆する表現が見られる。この箇所を取り上げたVism は,「得ている者（lābhin）がいるときに, 彼に現れるあり様（upaț̣hānākāra）をもつ て，それが述べられている」7) という簡潔な解説を示すのみだが, 1 (ābhin ${ }^{8)}$ と upatṭhānākāra ${ }^{9)}$ の意味や用例を考慮すると, 瞑想中にこうしたイメージが心に立 ち現れる体験を得て，それを受け入れている状態と理解されているようである. Vism がこの長老の体験を積極的に評価していないことは, この一文に続いて， 四方を鏡で囲まれたカラヴィーカ鳥が無限に広がる自己の鏡像を見て, 家族が来 
てくれたと思い込んで声を発してしまったという, ダンマアソーカの時代の伝説 （Cf. Sv II.453, Ps III.383）を喻え話として紹介していることからもわかる. 従って, 骨が四方の大地に広がるイメージは，対照相を段階的に増大する正規の修行の成 果ではなく，想念が生み出した幻影（妄想）にすぎず，長老はそのように心に顕 現する様相を捉えてしまった，というのがブッダゴーサの解釈と考えられる.

ところが, ダンマパーラの『清浄道論復註』（Vism-mht）では, 禅定で得た自在 力（vasipatti, cf. Vism 154）を使って，大地のどこに移動してもいつでも骨相を保持 している状態にあることを表現しているのだと解釈し，長老の体験を擁護しなが ら相の増大を回避するための新案が示されている ${ }^{10)}$.

Vismは, さらに聖典『法集論』(Dhammasangani, Dhs) の記述を取り上げて整合 性を検討する。Dhs は種々の禅定法について, 苦楽遅速の4種の道のり（patipada) $\times 4$ 種の対象 (ārammana) $=16$ 項目で分類しているが，その中に「無量（appamāna） の対象」が含まれている。無量の語は, 経典で確立した遍処の定義文（上記）中 にもあるように，一般的には対象を無限定に拡大することを意味する. Dhs では 多くの繰り返しが省略されるが, 不浄観にも16項目が機械的に配されているこ とから, この瞑想修行でも相の増大を認めるかのような記述になっている（Dhs 55).『法集論註』（Dhs-a 198,184）は, 教理的齟龉を避けるために，不浄観での「無 量」とは，膨脹して大きくなった身体などを意味する，という強引な説明を行 う。一方, この問題点に注目したVismは, Dhs-a と同様に死体の膨張やサイズ の大きな骨を瞑想対象にする場合と解釈するだけでなく, 増大させる人もいる が，それを行っても功徳 (ānisamsa) がないという第2の解釈を示す ${ }^{11)}$.

\section{3. 相を增大させない一一『解脱道論』の場合 上座部アバヤギリ派に帰属す} ると考えられる漢訳『解脱道論』（Vim, 大正 no. 1648, vol. 32）には, これと同じテー マに関してVism とよく似た議論が存在するという事実はこれまで研究者によっ て見過ごされてきた。

もしも人が欲望への嫌悪感（厭, patikūla）を願うなら, 自性身 ${ }^{12}$ の想を起こさせるべきで ある。なぜかといえば，もし自性身の想があれば，その想についてすぐに嫌悪感と彼分 （対照相）を得るからである．不浄想を増長させると，その身の相を除くことになってしま う. 自性身の想を除くと，すぐに嫌悪感を得ることはない，それゆえ，増長せしめてはな らない. ${ }^{13)}$

不浄観は欲を断つための修行なので,「身体 (死体) である」という知覚 (想念) を保ち続け，肉体の嫌悪感とともに対照相を得て禅定に入るべきなのであって， 
生身のリアルな知覚を離れて相を増大すると, 修行の目的からも外れることにな る. 従って, 不浄観瞑想において死体や骨の相を増大させてはならないというの が，Vimの論理である。しかし，Vimは，以下のように「ただし欲望をすでに断 ち切っている修行者であれば増大してもよい」と条件付きで容認する.

あるいは，もし無欲を得ていれば，大心（色界心）を修するために増長させることができ ると説く。阿毘是の説く如し, 「離欲等に処し, 初禅を正受し, 膖脤に住し, ‥及び, 無 量を事として起こす」と．大徳摨狗父（Bhadanta-Singālapitā）の偈を説く如し，「仏の家財 なる比丘，怖畏林に処す／既已に骨想を修し，普く此の地を満たせり／我れ知る，彼の比 丘速かに欲染を断ずべし」と. ${ }^{14)}$

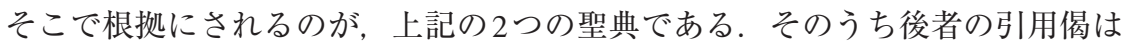
Th 18 であり, 前者の「阿毘曇」として引用される「処離欲等初禅正受住膖脹及 起無量事」はこれまでソースが特定されていなかった ${ }^{15)}$ が, 不浄観の膨張想を 説く『法集論』（Dhs 55）の “yasmim samaye rūpūpapattiyā maggam bhāveti vivicc’ eva kāmehi [vivicca akusalehi dhammehi savitakkạ̣ savicāraṃ vivekajạ̣ pītisukhaṃ] pațhamạ̣ jhānam upasampajja viharati uddhumātakasaññāsahagatạ̣ parittạ̣ appamānarammanam, tasmim samaye ${ }^{\cdots \cdots}{ }^{16)}$ ([ ] は PTS 版での省略箇所だが，漢訳でも「等」 として略されているのは興味墚い.) の下線部に対応する.

このように, Vimは無欲の修行者を想定して, 聖典の記述通りに不浄観におけ る相の増大を認める。しかし, 身至念や十不浄は肉体への愛着を抱えた領気質の 人が行うべき修行であること（Vism 114, Vim 412a20-21, cf. 林2020，24）を考えると， 果たしてそのような無欲の人にとって, そもそも不浄観瞑想を実践する意義や効 果は何なのかという疑問が残る. 上座部大寺派が Vim の解釈を採用しなかった のは, この矛盾に気づいていたからかもしれない.

4. 相を增大させない一一『長老偈註』の場合 最後に,「全体的に骨想を もってこの地面を満たした」という Th 18 の瞑想法をダンマパーラの『長老偈 註』（Th-a）がどのように解釈するかを見ておきたい.

「地面を」とは, 自己存在（attabhāva，身体）としての地面を.つまり，自己存在がここで は地面であると言われている.「誰がこの地面を考察（征服）するだろうか」（Dhp 44）な どの場合のように。…次のことが言われている。「一部分に関して得られた骨の想念をもっ て，全面的に自分のあるいは皆の自己存在をただ『骨』という〔想念〕のみで満たし続け ていた比丘である彼は（長老），その骨の禅定を足場となして観察していると，間もなく不 還道によって欲領を〔捨て去るだろう〕，あるいは「欲する意味で愛欲，染まる意味で情 
欲」ということで名を得た渇望を最高の道によって捨て去るだろう」と. ${ }^{17)}$

ここでは，「長老の自在力により大地のあらゆる場所で骨相を保っている状態」 と解した上述の『清浄道論復註』のダンマパーラとは異なり, 「地面」を身体 (attabhāva) の比喻とみなす，その際，解釈の根拠として『法句』（Dhammapada, Dhp） 第44偈の「大地」(pathavī) の語が挙げられているが, 『法句註』では確かに身体 に置き換えられている（Dhp-a 334: attabhāvasañkhātam paṭhaviṃ）。ただし，ウパニシャ ド的問答（なぞかけ）である Dhp 44-45における大地は気の利いた見立てにすぎな いので, この解釈を Th 18 にも適用するのは唐突な感じだが, ダンマパーラの解 釈に従えば, 長老の瞑想は, 観察した骨の一部を自分の全身に当てはめ, さらに 他の人々すべての身体に広げる方法であった，ということになる．

説一切有部の不浄観瞑想 ${ }^{18)}$ は，骨の一部から自分の全身骨格をイメージし， 他者の体, それからさらに大地に骨が充満するようにイメージしていくものであ り，Th-a が示す瞑想法と類似する部分がある。こうした方法がインド仏教にお いてある程度共有されていて，それが上座部の教義に混入したのかもしれない が, 少なくともパーリ註釈文献においても，標準的な手順や形式とは異なる実践 や例外的な多様な状況が想定されている.

例えば，不浄観は生きている人体を眺めた場合にも起こるとして，Vism 194 や Dhs-a $200^{19)}$ には, 女性の歯を見たマハ一ティッサ長老の事例と象に乗る王（ダン ミカティッサ）を見たサンガラッキタ長老の侍者の沙弥の事例が紹介されている. 前者の詳細な内容は別の箇所（Vism 20-21）に語られている. マハーティッサ長老 は，すれ違いざまに大笑いした女を見て，「彼女の歯骨について不浄想を得て， 阿羅漢の状態に達した」(tassā dantațthike asubhasaññam patilabhitvā arahattam pāpunii). そ の後, 彼女を追って来た夫から所在を問われると，「私は知らない，女であれ男 であれ，ここから去ったかどうかは，だがしかし，この骨の集合体が (aț̣isanghātọ) 大道を行くのは〔知っている〕」， 長老は答えたとされる.

また,「ヴァッタカ・ジャータカ」(Ja no. 118) では, 男を誘惑しょうとして女 が微笑むが，男は女の歯骨を「眺めていて歯骨に関して相を把捉した，骨想が生 じた。その体全体すらも骨鎖の如く洞察した」と述べられる ${ }^{20)}$.

そもそも異性を対象にする不浄観自体が上座部の修養規程にそぐわないが，こ のように他人の小さな歯骨から相手の全身に拡大し，人体標本の骸骨のように想 念する方法も, 上座部では不浄観瞑想の一種として許容されていた. 
5. まとめ 上座部では，もともと古代インドの伝統的な修行道を背景にして開 発されてきた多種多様な初期仏教の瞑想を整理する過程を経て, 部派特有の修行 理論や実践体系の構築を試みてきた。瞑想対象のイメージを広げていくという遍 処特有の実践法を他の瞑想に適用しない, という内容を含む上座部の基本的な修 養規程（vidhi, bhāvanāvidhāna, bhāvanānaya）が形成されたのは，Vism やVim の成立期 よりも古く, それらに引用・言及される古註釈群や古長老たちの時代に遡ると考 えられる。

上座部の註釈家たちは，こうした理念から聖典を振り返り，パーリ三蔵の随所 で不合理に見える言説を丁寧に取り上げて正当化を図ってきた.Vismにおいて， ブッダゴーサが骨想に代表される不浄観瞑想に焦点を当てて相の増大を否定する 議論を展開したのは，まさにその実践の痕跡が経典（Th）とアビダンマ (Dhs) に 存在することが以前から知られていて, 上座部内部で教理上の解決が必要とされ ていたからであろう。それは, Vism に先行するアバヤギリ派のVimにおいて同 じテーマの議論が見られるだけでなく, そこでも同じ2つの聖典の記述箇所をめ ぐる解釈が試みられていることから裏づけられる.

Vim とVism とでは, 聖典の解釈が明確に異なるが，この点は部派の教理的差 異を示す指標とはならない。 むしろ, 大寺派内部ですら Vismの解釈はダンマ パーラの Th-a に継承されておらず, Dhs-a も Vism-mht もそれぞれ独自の解釈を 有する状況を鑑みれば, ブッダゴーサ以前も以降も, 理念を逸脱しない限り, 実 践方法や体験の捉え方にはある程度の幅が許容されていたことが伺える.さらに 言えば，無視したり型どおりの解釈を繰り返したりせず，これほど注目され解釈 が多様化する背景には, 有部論書にあるような「骨想を大地の果てまで満たす修 行」が上座部周辺や内部でも伝承されていた実態があったのかもしれない.

様々な実践の試みと体験の中から理論は生まれるが, それが分類整備されて体 系化されると, 今度は逆に理論が実践にフィードバックされ, 実践を規定し制限 していくことになる。こうした逆転現象や相互作用は聖典と註釈にも起こる. パーリ註釈文献は, 部派の教理体系を正当化するために聖典の権威をもって根拠 づける一方で, 理論に合致させる「合理的」解釈を生み出しながら聖典を従わせ る機能をもつ.このような観点から聖典と註勫の関係を眺めると, パーリ註釈文 献にはパーリ三蔵に従属する補助的資料という立場に留まらず, 主従関係を反転 させる影響力をもった資料的価值を見出すことができるだろう。 
1) Vism 123: tassa kir' āyasmato kasitaț̣hānaṃ oloketntassa tạ̣ țhānappamāṇam eva nimittaṃ udapādi. so tạ̣ vaḍ̣̣hetvā pañcakajjhānāni nibbattetvā'.. Vism 126: tạ̣ nimittạ̣ vaḍụhetvā appanam adhigantuṃ sakkoti. Vism 375: uppanne nimitte tạ̣ vaḍ̣hetvā appanādhigamo bhāro.

2) Vism 111-112: vaḍ̣hanāvaḍ̣hanato ti imesu cattālīsāya kammaț̣hānesu dasakasinān'eva ( $E^{e}$ :

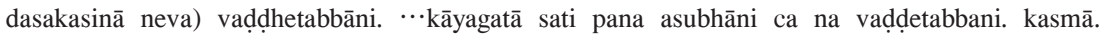
okāsena paricchinnattā ānisamsābhāvā ca. sā ca nesaṃ okāsena paricchinnatā bhāvanānaye àvibhavissati. tesu pana vaḍ̣hitesu kuṇaparāsi yeva vạ̣̣hhati, na koci ānisaṃso atthi.

3) Vism 184: idạ̣ sarīrạ̣ adho pādatalena, upari kesamatthakena, tiriyạ̣ tacena paricchinnam, yathā paricchinne ca țhāne dvattimsa-kunapabharitam evā ti vavatthapetabbaṃ.

4) Vism 192: tassa tassa aț̣ino pariyantavasena paricchedato vavatthapetvā, yad ev' ettha pākatạ̣ hutvā upatthāti, tam gahetvā appanā pāpunitabbā.

5）神通によって巨大な山や大地を化作する場合（Vism 155, 376, etc.）も, 地遍の対象であ る大地の相の空間的増大と関連付けられるかもしれない.

6）上座部の外典文書としての Sopākapañhavyākarana については，拙稿 Hayashi 2011 参照. ただし，瞑想の深まりとともに骨想が個別の相を離れてより一般化抽象化した色想に変 化することによって，骨であるという観念が不明瞭となり，色であるという観念が明瞭 になる，という筆者の説明（p. 12）は誤りで，水野弘元訳『南伝大蔵経62』（p. 223）の 通り, 前者（色想）を遍処の相, 後者（骨想）を不浄観の相と理解する方が適切と思わ れる。また，この議論の文脈から vibhūtaの語義は「明瞭な」（clear）ではなく, vibhū と 同義で「遍在している」（being everywhere, all-pervading, omnipresent）の方がよりふさわ

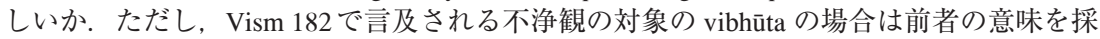
用すべきと思われる.

7) Vism 112: lābhissa sato upatṭhānākāravasena vuttam.

8）lābhin という単語は, その獲得（修得）対象が禅定や神通などの場合（Vin IV.26-27, MNd I.231, Patis I.35, Vibh 330）もあるが, 一般的には, 施物や利得や世俗的な欲求充足 などを得る人，受益者を意味する，また，文脈によっては，直観体験を得ているために 諸前提を当然とみなして受け入れてしまう人を意味する場合がある（Cf. PTSD, s.v. lābhin)。推測に基づいて常住論を唱える沙門・バラモン（DN I.16）に関連して，パーリ 註釈（Sv I.106-107）では, 推測者（takkin）を4種類に分類するが，その1つが, 過去に 得た自分の経験から未来もこうなるだろうと憶測するのが「得ている人としての推測 者」（lābhī takkiko）である。一方，断滅論に陥る人（DN I.34）に関して, 註釈（Sv I.120） は lābhin と alābhin に分類する．前者は，阿羅漢の死後の不再生を天眼で見て，あるいは (一般人の) 死だけを見て再生を見ることができないことで断滅論を主張する人である. これらは lābhin という 1 語で, 自分の限られた経験を過大に受けとめてしまう人を指す.

9）Vism で upatṭhānākāra という場合, 瞑想中に想念（saññā）として現れる心像の様態を 意味し, 対照相の内容であったり（Vism 126）, 単なる妄想であったりもする（Vism 187).

10) Vism-mht $\left(N^{e}\right)$ I.238-239: thero hi paramāya vasipattiyā assamaṇdale assam sārento viya yattha tattha nisinno pi thito pi tạ̣ jhānam samāpajjateva.（つまり，長老は最高の自在力の獲得に よって，まるで乗馬場で馬を走らせる者のように，どこにいても坐っていようが立って いようがその禅定に入るのみ。それゆえ，この人にとっては全面的に相が増大したかの ように生じた.）

11) Vism 112: ekacco hi uddhumātake vā atthike vā mahante nimittạ̣ gạ̣hāti, ekacco appake. iminā pariyāyena ekaccassa parittārammaṇaṃ jhānaṃ hoti, ekaccassa appamāṇārammaṇan ti. yo vā etam 
vaḍ̣hane ādīnavam apassanto vaḍ̣heti, tạ̣ sandhāya appamāṇārammaṇan ti vuttam. ānisamsāābāvā pana na vaḍdhetabbānī ti.（なぜなら， ある者は，膨脹したものであれ，ある いは骨であれ，大きなものについて相を把握するし，ある者は小さなものについて〔相 を把握する]，この解説方法によって，ある者にとっては対象が小さな禅定となり，ある 者にとっては対象が無量の〔禅定となる〕，と．あるいは，増大させることに危難（過 失）を見い出さない者はこれを増大させるが，彼に関して無量の対象があると言われ る.しかし，功徳がないことから，〔不浄どもは〕増大させるべきではない，と.）

12）「自性身」とは, attabhāva（自己存在，身体）を直訳した「自性」と意訳の「身」を合 成した訳語か.「彼の坐禅人，自性身（pakativanna）を捨てて，童子形を現し」（Vim 441b5, cf. Vism 378）の用例もあるが, 本来の姿, 生身の肉体を意味する.

13）Vim 426b16-20: 若人楽厭欲，令起自性身想. 何故. 若有自性身想，於想速得厭彼分故. 已令増長不浄想，是其身相得除. 已除自身想，不速得厭. 是故不應令増長.

14）Vim 426b20-25: 又説若得無欲, 為修大心, 成令増長. 如阿毘是説. 処離欲等初禅正受 住膖脹及起無量事. 如大徳摨狗父説偈. 比丘仏家財於怖畏林処 既已修骨想普令満此地 我知彼比丘速当断欲染.

15）Cf. Bapat 2009, 62; 水野 1996; 干潟 1933, 130, n. 18:「この句出所を明にせず.」; Ehara et al. 1995, 140, n. 1: “Not traced.”; 浪花 2001, 24, 161; 洞崧 2017, 131; 洞崧 2018, 627.

16「拉よそそのとき色に生じるために道を修める, 諸欲をまさに離れて諸悪を離れて： 〔そして〕有尋有伺にして遠離から生じる喜楽ある初禅に踏み込んだままでいる, 膨脹 想を伴った〔初禅に〕，小にして無量を対象とする〔初禅に〕：そのとき…‥」

17) Th-a I.75-76: paṭhavin ti attabhāvapațhavim. attabhāvo hi idha paṭavī ti vutto, "ko imam

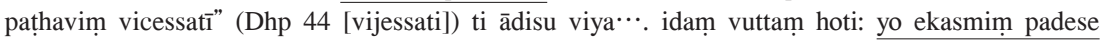
laddhāya atthikasaññaya sakalam attano sabbesam vā attabhāvam “ațhī” tveva pharitvā thito bhikkhu, so tạ̣ aț̣hikajjhānam pādakaṃ katvā, vipassanto na ciren’ eva anāgāmimaggena kāmarāgạ̣ sabbạ̣ vā kāman'aț̣nena kāmo, rajjan' aț̣nena rāgo ti ca laddhanāmaṃ tạnham aggamaggena pajahissatī ti.

18）説一切有部では，足指の骨から全陸地まで骨を増大・縮小させるのが不浄観の基本. 『俱舎論』「賢聖品」によると，初心者は自分の足指など体の一部を観想し，それが膿ん だ肉だと理解して，肉を剥ぎ取ってその中の骨を想像し，全身骨格をイメージしてか ら, 他人の骨, 僧坊, 園林, 〔村〕, 国土に, そして海で限られた大地に骨が充満してい くのを確認し，それから逆をたどって1つの骨へと縮小させる（AKBh 338, 5-9, 『阿毘達 磨俱舎釋論』T1558, vol. 29, 270a3-12, 『阿毘達磨俱舎論』T1558, vol. 29, 117c3-12, cf. 『順正 理論』T1562, vol. 29,671c8-27. Cf. 櫻部 - 小谷 1999, 81)。遡ると, 『雑阿毘量心論』(T1552, vol. 28，933c26-934a15）では, 髑髏骨から足骨, さらに坐所, 僧房から僧院, 一村, 一 国，四海大地に至るまで骨が充満するようにイメージする不浄観瞑想，さらに，『阿毘 達磨大毘婆沙論』（T1545, vol. 27, 205b-c. Cf. 839c-840a, T1546, 153b）では，楽略者は墓場 から僧房に戻って自骨にあてはめて観察し，楽広者は自骨・外骨，それから部屋に充 満, 海で限られた大地にまで充満させることを説くことから, 有部では, 骨想の大地拡 大という不浄観は一貫している。 『成実論』の「不浄想品」（T1646, vol. 32, 349c-350a）に はこのような解説がない.『坐禅三昧経』(T614, vol. 15, 272a) では, 骨想を行っていると, 白骨が放つ白瑪瑙のような白光のイメージが遍満すると観察する（『瑜伽師地論』と有部 論書や禅経典の比較については, 阿部2018参照)。また, 『大智度論』（T1509，vol. 25, 215b20-23）にも，白骨から光が流出して内外を照らすと述べられる. 四念処の身体随観 に含まれる「九墓地」の第7では,「もろもろの骨がほら貝の色のように白い」と観察す る（DN II.297, etc.）が，上座部（Vism 192）では，骨の白さに注目する瞑想はむしろ白遍 
処に移行したと解釈され，それならば相の増大は起こることになる.

19) Vism 194, Dhs-a 200 (cf. Spk III.175): tad etạ̣ iminā lakkhaṇena na kevalaṃ matasarīre, dantaț̣hikadassāvino pana Cetiyapabbatavāsino Mahā-Tissattherassa viya, hatthikkhandhagatạ̣ rājānaṃ olokentassa Sangharakkhitattherūpațhākasāmaṇerassa viya ca jīvamānakasarīre pi upatțhāti.（その際，これ (不浄) は，ただ単に死体だけこのような（嫌悪感などの）特徵 をもって〔現れるの〕でなく，歯骨を見たチェーティヤ山の住人のマハーティッサ長老 に〔生じた〕如く, そして象の背に乗った王を眺めていたサンガラッキタ長老の侍者で ある沙弥に〔生じた〕如く，生きている体にすら現れる.）

20) Ja-a i.433: pahațthākārena aggadante vivaritvā sitạ akāsi. seț̣iputto oloketvā dantațhike nimittạ̣ gaṇhi. aț̣hikasaññạ̣ uppajji. sakalam pi tạ̣ sarīraṃ aț̣hikasaṃkhalikā viya paññãyi.

〈使用テクストと略号〉

AKBh: Abhidharmakośabhāsya of Vasubandhu. Ed. P. Pradhan. Patna: K. P. Jayaswal, 1967.

Vism-mhṭ $\left(\boldsymbol{N}^{e}\right)$ I: Buddhaghosa's Visuddhimaggo [Vol. 1] with Paramatthamañjūsāțīkā of Bhadantācariya Dhammapāla. Ed. Rewatadhamma. Pāli-Granthamālā, no. 3. Varanasi: Varanaseya Sanskrit Vishwavidyalaya, 1969.

その他のテクストと略号は A Critical Pāli Dictionary に従う.

\section{〈参考文献〉}

Bapat, P. V. (1937) 2009. Vimuttimagga and Visuddhimagga, a Comparative Study. Kandy: Buddhist Publication Society.

Ehara, N. R. M., Soma Thera and Kheminda Thera. (1961) 1995. The Path of Freedom (Vimuttimagga). Kandy: Buddhist Publication Society.

Hayashi Takatsugu. 2011. "On "Sopākapañhavyākaraña" in the Visuddhimagga." Bukkyō Kenkyū 39: 1-18. Norman, K. R. 1969. The Elders' Verses I Theragāthā. London: Pali Text Society. 阿部貴子 2018 「声聞 地』の不浄観一一光明想を再考する一—」『印仏研』67(1)：381-375. 櫻部建・小谷信 千代 1999 『俱舎論の原典解明 賢聖品』法蔵館. 釋洞崧 2017 『《解脱道論》「行處」與 《清浄道論》「業處」之比較研究』怡保観音堂法雨出版小組. 2018 『《解脱道論》 註解 上下』法鼓文理学院. 長井眞琴 1975 「解脱道論とヴィスッディマッガとの対照 研究」『南方所傳佛典の研究』国書刊行会, 220-244. 浪花宣明訳 2001『解脱道論』新 国訳大蔵経・論集部 5. 大蔵出版. 林隆嗣 2020 「瞑想の阻害と負の意識反応——清浄 道論』を中心として—」『こども教育宝仙大学紀要』11: 21-30. 干潟龍祥訳 1933 『解脱道論』国訳一切経・論集部7. 大東出版. 水野弘元 (1964) 1978 『パーリ佛教を中 心とした佛教の心識論』ピタカ. 水野弘元 (1939) 1996 「解脱道論と清浄道論の比較 研究』—P.V. Bapat」『仏教文献研究』水野弘元著作選集 1. 春秋社, 143-170.

（本研究は JSPS 科研費 JP18H05302の助成を受けたものです. )

〈キーワード〉 不浄観, ブッダゴーサ, 清浄道論, 解脱道論, ダンマパーラ

(こども教育宝仙大学教授, $\mathrm{PhD}$ ) 